\title{
Photosynthetic responses of tropical tree species from different successional groups under contrasting irradiance conditions
}

\author{
RAFAEL V. RIBEIRO ${ }^{1}$, GUSTAVO M. SOUZA ${ }^{2,4}$, RICARDO F. OLIVEIRA ${ }^{3}$ and \\ EDUARDO C. MACHADO ${ }^{1}$
}

(received: July 4, 2003; accepted: November 18, 2004)

\begin{abstract}
Photosynthetic responses of tropical tree species from different successional groups under contrasting irradiance conditions). This study evaluated the photosynthetic responses of seven tropical trees of different successional groups under contrasting irradiance conditions, taking into account changes in gas exchange and chlorophyll $a$ fluorescence. Although early successional species have shown higher values of $\mathrm{CO}_{2}$ assimilation (A) and transpiration (E), there was not a defined pattern of the daily gas exchange responses to high irradiance (FSL) among evaluated species. Cariniana legalis (Mart.) Kuntze (late secondary) and Astronium graveolens Jacq. (early secondary) exhibited larger reductions in daily-integrated $\mathrm{CO}_{2}$ assimilation (DIA) when transferred from medium light (ML) to FSL. On the other hand, the pioneer species Guazuma ulmifolia Lam. had significant DIA increase when exposed to FSL. The pioneers Croton spp. trended to show a DIA decrease around 19\%, while Cytharexyllum myrianthum Cham. (pioneer) and Rhamnidium elaeocarpum Reiss. (early secondary) trended to increase DIA when transferred to FSL. Under this condition, all species showed dynamic photoinhibition, except for $C$. legalis that presented chronic photoinhibition of photosynthesis. Considering daily photosynthetic processes, our results supported the hypothesis of more flexible responses of early successional species (pioneer and early secondary species). The principal component analysis indicated that the photochemical parameters effective quantum efficiency of photosystem II and apparent electron transport rate were more suitable to separate the successional groups under ML condition, whereas A and E play a major role to this task under FSL condition.
\end{abstract}

Key words - chlorophyll fluorescence, flexibility response, functional groups, gas exchange, high irradiance

RESUMO - (Respostas fotossintéticas de espécies arbóreas tropicais de diferentes grupos sucessionais em condições contrastantes de irradiância). Neste estudo foram avaliadas as respostas fotossintéticas à alta irradiância de sete espécies arbóreas tropicais de diferentes grupos sucessionais, através de alterações nas trocas gasosas e fluorescência da clorofila $a$. Embora as espécies pioneiras tenham apresentado maiores valores de assimilação de $\mathrm{CO}_{2}(\mathrm{~A})$ e transpiração (E), não houve padrão de resposta do curso diário das trocas gasosas entre as espécies estudadas na condição de alta irradiância (FSL). Cariniana legalis (Mart.) Kuntze e Astronium graveolens Jacq. apresentaram reduções significativas na quantidade de $\mathrm{CO}_{2}$ assimilado durante o dia (DIA) quando transferidas da condição de média irradiância (ML) para FSL. A pioneira Guazuma ulmifolia Lam. mostrou aumento significativo de DIA quando exposta a FSL. Já as pioneiras Croton spp. tenderam a apresentar reduções em DIA ao redor de 19\%, enquanto Cytharexyllum myrianthum Cham. (pioneira) e Rhamnidium elaeocarpum Reiss. (secundária inicial) mostraram ligeiro incremento de DIA. Sob condição de FSL todas as espécies apresentaram fotoinibição dinâmica, exceto C. legalis que mostrou fotoinibição crônica. Considerando os processos fotossintéticos diários, nossos resultados suportam a hipótese de maior flexibilidade de resposta das espécies pioneiras. A análise de componentes principais indicou que os parâmetros fotoquímicos eficiência quântica efetiva do fotossistema II e a taxa aparente de transporte de elétrons foram mais adequados para a distinção dos grupos sucessionais em ML, ao passo que A e E apresentaram papel determinante na condição de FSL.

Palavras-chave - alta luminosidade, flexibilidade de resposta, fluorescência da clorofila, grupos funcionais, trocas gasosas

\section{Introduction}

Centuries of natural resources exploration have degraded the tropical forests around the world, where

1. Instituto Agronômico de Campinas, Centro de Pesquisa e Desenvolvimento em Ecofisiologia e Biofísica, Caixa Postal 28, 13001-970 Campinas, SP, Brasil.

2. Universidade do Oeste Paulista, Faculdade de Ciências Agrárias, Campus II, Rodovia Raposo Tavares, km 572, 19067-175 Presidente Prudente, SP, Brasil.

3. Universidade de São Paulo, Escola Superior de Agricultura "Luiz de Queiroz", Departamento de Ciências Biológicas, Caixa Postal 9, 13418-900 Piracicaba, SP, Brasil.

4. programs of restoration and sustainable forest management are important and necessary. In this way, the use of adequate tree seedlings in specific programs of forest or recovery of degraded areas is limited due to the lack of knowledge concerning the plant physiological responses in such complex ecosystems. The acclimation (i.e., the physiological adjustment by an organism to an environmental change) of seedlings grown in shading nurseries to open environment (full sun-light) may be a decisive process on which plants depend to survive. In addition, different successional groups of tropical tree species show specific environmental demands to light, nutrients, and 
temperature (Strauss-Debenedetti \& Bazzaz 1996).

According to the spatial and temporal plant distribution in the forest mosaic, where plants have different strategies to survive and develop (Pickett et al. 1987, Luken 1990), tree species may be separated into two successional groups based at growth characteristics and shade adaptation: $i$ ) an early successional group (pioneer and early secondary species), which has light demand, and $i$ ) a late successional group, which is shade tolerant (late secondary species) (Bazzaz \& Pickett 1980). If early and late successional plants have different photosynthetic characteristics (Strauss-Debenedetti \& Bazzaz 1996), these differences will be expected to arise when plants are grown under similar conditions, especially under high irradiance.

Photochemical reactions of photosynthesis are sensible to high irradiance condition, being affected by decreased potential and effective quantum efficiency of photosystem II (PSII) (Osmond 1994). These events decrease electron flow through photosystems, leading to lower ATP and NADPH formation and decreasing the $\mathrm{CO}_{2}$ fixation. According to Critchley (1998), a reduction in the total photochemical capacity is known as photoinhibition, which may be a photoprotective mechanism (dynamic photoinhibition) or represent damage of PSII (chronic photoinhibition) due to excessive light energy (Osmond 1994). In addition to excessive irradiance, photoinhibition may be enhanced by decrease in electron sink for $\mathrm{CO}_{2}$ fixation under high temperature (Laisk et al. 1998).

As high irradiance is associated to high temperature and leaf-to-air vapor pressure difference, it is expected negative effect on photosynthesis by alternative electron sinks under high temperatures (Laisk et al. 1998), and by stomatal closure under high atmospheric demand to water vapor (Jones 1998, Nobel 1999). Low stomatal conductance may affect photosynthesis by preventing $\mathrm{CO}_{2}$ flow to carboxylation sites (Farquhar \& Sharkey 1982). Photosynthetic activity depends upon both the efficiency of the photochemical apparatus and the stomatal control of gas exchange, being regulated according to specific characteristics of different successional groups.

It is considered that early successional species show higher responsiveness to irradiance increase than late successional ones (Chazdon et al. 1996, StraussDebenedetti \& Bazzaz 1996). Nevertheless, Pearcy (1987) sustains that late successional species should respond promptly to peaks of irradiance when growing under a sunfleck dynamic at understorey. This responsiveness could be considered as phenotypic plasticity, which is a change in an organism's characteristics in response to an environmental signal (Schlichting \& Smith 2002). Homeostasis is another fundamental aspect of biological response to environmental changes, which is a self-regulating mechanism that allows the organisms to maintain a dynamical equilibrium with their parameters varying between limits of tolerance (Cannon 1932). According to Kauffman (1993), homeostasis is the system capacity to return to its initial condition after an external disturbance on its biological parameters. Thus, homeostasis can be refereed as a general expression indicating the tendency of the internal environment of an organism to be maintained constant (Møller \& Swaddle 1997).

Although the functional group hypothesis has been supported by previous studies (Mulkey et al. 1993, Ellis et al. 2000), there is not a reliable criterion that establishes a clear consensus in relation to species successional status and the forest dynamics. In fact, the physiological responses of tropical tree species from different successional groups to environmental changes are not completely understood (Strauss-Debenedetti \& Bazzaz 1996, Ellis et al. 2000). Accordingly, the objectives of this study were: i) to evaluate differences in the phenotypic plasticity and homeostasis of different successional groups from nursery condition to the open environment, and ii) to characterize the daily physiological responses of tropical species from different successional groups to increasing irradiance, measuring diurnal changes in leaf gas exchange and chlorophyll $a$ fluorescence.

\section{Material and methods}

Plant material and species description - Seedlings of seven species of tropical Brazilian trees from different successional groups were evaluated considering their responses to increasing irradiance. Three six month-old seedlings of each species were grown in $8 \mathrm{~L}$ plastic pots with oxisoil. Seedlings were irrigated daily. According to Lorenzi (1992), Gandolfi et al. (1995) and Martins \& Rodrigues (2002), Croton urucurana Baill. (Euphorbiaceae) is a deciduous tree typical from humid areas, belonging to early forest successional stages, while Croton floribundus Spreng. (Euphorbiaceae), also a deciduous or semi-deciduous pioneer species, grows in dry areas. Cariniana legalis (Mart.) Kuntze (Lecythidaceae) is a semi-deciduous tree from dry regions, which appears at final forest successional stages, i.e, a late secondary species. Species as Astronium graveolens Jacq. (Anacardiaceae) and Rhamnidium elaeocarpum Reiss. (Rhamnaceae) are deciduous trees from humid areas, 
appearing both in early (early secondary) or late (late secondary) successional stages. Guazuma ulmifolia Lam. (Sterculiaceae) and Cytharexyllum myrianthum Cham. (Verbenaceae) are pioneer species, the former is a semideciduous tree typical from dry regions and the latter is a deciduous species from humid areas.

Irradiance conditions - The seedlings were maintained under medium irradiance (ML) environment (34\% of full sun-light) for 30 days, simulating a nursery condition. Measurements of leaf gas exchange and chlorophyll $a$ fluorescence were taken at ML and after $72 \mathrm{~h}$ of seedling transference to the high irradiance (FSL) environment (in open area located in Piracicaba, SP Brazil, $22^{\circ} 42^{\prime} \mathrm{S}, 47^{\circ} 38^{\prime} \mathrm{W}, 546 \mathrm{~m}$ of altitude). Air temperature, photosynthetic photon flux density (PPFD) and leaf-to-air vapor pressure difference $\left(\mathrm{VPD}_{\text {leaf-air }}\right)$ in both $\mathrm{ML}$ and FSL conditions are showed in figure 1. Physiological evaluations (leaf gas exchange and chlorophyll $a$ fluorescence) were carried out in both irradiance environments, in the same three plants of each species, randomly disposed in a $6 \mathrm{~m}^{2}$ area, in the same leaf fully expanded. The measurements were taken between 7:30 and 16:30 $\mathrm{h}$ in intervals of $1 \mathrm{~h}$ (except between 11:30 and 13:30 h) in a clear day (without clouds) in each irradiance environment in August 2002.

Leaf gas exchange measurements $-\mathrm{CO}_{2}$ assimilation $\left(\mathrm{A}, \mu \mathrm{mol} \cdot \mathrm{m}^{-2} \cdot \mathrm{s}^{-1}\right)$, stomatal conductance $\left(\mathrm{gs}, \mathrm{mol} \cdot \mathrm{m}^{-2} \cdot \mathrm{s}^{-1}\right)$, transpiration $\left(\mathrm{E}, \mathrm{mmol} . \mathrm{m}^{-2} \cdot \mathrm{s}^{-1}\right)$, and intercellular $\mathrm{CO}_{2}$ concentration $\left(\mathrm{Ci}, \mu \mathrm{mol} . \mathrm{mol}^{-1}\right)$ were taken with a portable infrared gas analyzer (LI-6400, Li-Cor, Lincoln, NE, USA). Before measurements, the gas exchange system was zeroed using $\mathrm{CO}_{2}$-free and $\mathrm{H}_{2} \mathrm{O}_{\text {vapor }}$-free air. We used a leaf chamber of $6 \mathrm{~cm}^{2}$ and natural irradiance. The air entering the gas analyzer was taken from height of $2 \mathrm{~m}$ above ground and passed through $10 \mathrm{~L}$ mixing volume before reaching the leaf chamber. Air $\mathrm{CO}_{2}$ concentration was $360 \pm 10 \mu \mathrm{mol}^{\mathrm{mol}}{ }^{-1}$ during measurements.

Chlorophyll $a$ fluorescence measurements - Chlorophyll $a$ fluorescence was recorded using a PAM-2000 portable fluorometer system (Walz, Effeltrich, Germany). The fluorometer was operated via a Palm-top computer (Hewlett Packard Co., Idaho, USA), which also stored the measured fluorescence data. A special leaf clip holder was used (2030-B, Walz, Effeltrich, Germany), with which the fiberoptics could be adjusted at a defined angle $\left(60^{\circ}\right)$ and a fixed distance relative to the leaf. This leaf clip holder has a micro-sensor to monitor PPFD and a thermocouple to measure lower leaf surface temperature. Measurements were taken in both light-and darkadapted $(30 \mathrm{~min})$ leaves. The following parameters were assessed in order to evaluate photochemical activity: potential $\left[F_{v} / F_{m}=\left(F_{m}-F_{o}\right) / F_{m}\right]$ and effective $\left[\Delta F / F_{m}{ }^{\prime}=\left(F_{m}{ }^{\prime}-F\right) /\right.$ $\mathrm{F}_{\mathrm{m}}{ }^{\prime}$ ] quantum efficiency of photosystem II (PSII) (Genty et al. 1989), and the apparent electron transport rate (ETR) through PSII $\left(\mathrm{ETR}=\Delta \mathrm{F} / \mathrm{F}_{\mathrm{m}}{ }^{\prime} \times \mathrm{PPFD} 02 \times 0.5 \times 0.84\right)($ Krall \& Edwards 1992). Photochemical quenching $\left[q P=\left(F_{m}{ }^{\prime}-F\right) /\left(F_{m}{ }^{\prime}-F_{o}{ }^{\prime}\right)\right]$ and non-photochemical quenching $\left[\mathrm{NPQ}=\left(\mathrm{F}_{\mathrm{m}}-\mathrm{F}_{\mathrm{m}}{ }^{\prime}\right) / \mathrm{F}_{\mathrm{m}}{ }^{\prime}\right]$ were calculated according to Van Kooten \& Snel (1990). $F_{m}$ and $F_{o}$ were maximum and minimum fluorescence yields of darkadapted leaves, respectively, and $\mathrm{F}_{\mathrm{m}}$ ' and $\mathrm{F}$ were maximum and steady-state fluorescence yields in light-adapted state, respectively. $\mathrm{F}_{\mathrm{o}}$ ' was the minimum fluorescence yield after photosystem I (PSI) excitation by far-red light. For the calculation of ETR, 0.5 was used as the fraction of excitation energy distributed to PSII, and 0.84 was used as a general fraction of total irradiance absorbed by leaves (Demmig \& Björkman 1987).

Data analysis - The experimental design was in random blocks with three replicates (leaves from different plants), where the factors were the irradiance conditions (ML and FSL) and the time of day. Data were submitted to variance analysis procedures (ANOVA) and the mean values compared by the Tukey test $(\mathrm{p}<0.05)$. Ordination multivariate analysis by principal components (PCA) was used in order to verify the global influence of all parameters evaluated on the species grouping in each irradiance regime. PCA is a linear dimensionality reduction technique, which identifies orthogonal directions of maximum variance in the original data, and projects the data into a lower-dimensionality space generated by a sub-set of the highest-variance components (Manly 1994, McGarigal et al. 2000). In this study a space of two dimensions (two principal components), which was demarcated by two axes labeled pc1 and pc2, was suitable to our analysis. The software PC-ORD version 3.12 (MJM Software Design, Gleneden Beach, Oregon, USA) was used.

\section{Results}

Environmental conditions - Mean solar global radiation in August 2002 (local weather station) was 14.4 MJ.m. $\mathrm{m}^{-2} \cdot \mathrm{d}^{-1}$, with an average relative humidity of $77 \%$ and maximal air temperature above $31^{\circ} \mathrm{C}$. Air temperature $\left(\mathrm{T}^{\circ} \mathrm{C}\right)$ changed from 21 to $39^{\circ} \mathrm{C}$, and from 21 to $36^{\circ} \mathrm{C}$ in FSL and ML, respectively. The leaf-toair vapor pressure difference $\left(\mathrm{VPD}_{\text {leaf-air }}\right)$ varied from 0.6 to $5.3 \mathrm{kPa}$ under FSL, while this variation was from 0.7 to $3.8 \mathrm{kPa}$ under ML. PPFD changed from 100 to $1,800 \mu \mathrm{mol} . \mathrm{m}^{-2} . \mathrm{s}^{-1}$ under FSL, but at ML these values varied between 50 and $600 \mu \mathrm{mol} . \mathrm{m}^{-2} . \mathrm{s}^{-1}$ (figure 1). The daily-integrated PPFD was around $13.83 \mathrm{~mol} \cdot \mathrm{m}^{-2} \cdot \mathrm{d}^{-1}$ under ML and around $39.60 \mathrm{~mol} \cdot \mathrm{m}^{-2} \cdot \mathrm{d}^{-1}$ in FSL.

Effects of high irradiance on daily gas exchange-Under FSL, the higher $\mathrm{CO}_{2}$ assimilation (A) values were observed in C. myrianthum, C. floribundus, C. urucurana, and G. ulmifolia. However, $C$. myrianthum and $C$. floribundus reached their maximal A rates around 14:30 h, while $C$. urucurana and G. ulmifolia showed the highest A values at 8:30 h. These four species showed the highest A between 9:30 and 11:30 $\mathrm{h}$ under ML condition. The A rates of 


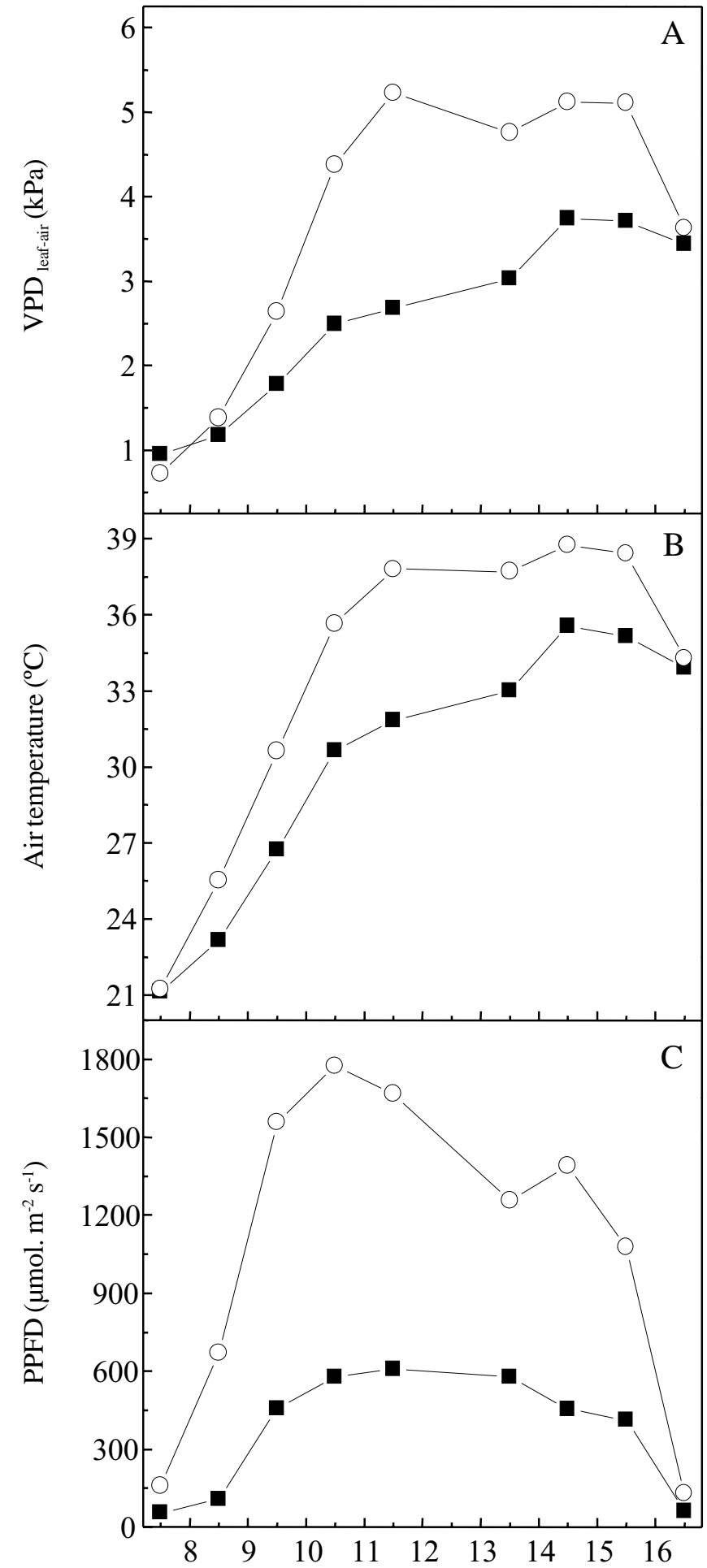

Time of day (h)

Figure 1. Daily course of leaf-to-air vapor pressure difference, $\mathrm{VPD}_{\text {leaf-air }}(\mathrm{A})$, air temperature $(\mathrm{B})$, and photosynthetic photon flux density, PPFD (C) at medium (ML, closed squares) and high (FSL, open circles) irradiance conditions. $-\mathbf{-}-=\mathrm{ML},-\mathrm{O}-=$ FSL.
C. urucurana, C. myrianthum, $R$. elaeocarpum and C. floribundus showed a quite drop around $9: 30 \mathrm{~h}$ at FSL condition, recovering in afternoon. The diurnal change of A in $C$. myrianthum and $R$. elaeocarpum did not present significant differences $(\mathrm{p}>0.05)$ between FSL and ML conditions. The other species exhibit significant differences $(\mathrm{p}<0.05)$, mainly between 9:30 and 14:30 h (figure $2 \mathrm{~A}-\mathrm{G}$ ), corresponding to the hours of the highest $\mathrm{T}^{\circ} \mathrm{C}$, PPFD and $\mathrm{VPD}_{\text {leaf-air }}$ (figure 1).

An analysis of daily-integrated $\mathrm{CO}_{2}$ assimilation (DIA) revealed some interesting patterns (table 1). The species $C$. legalis and A. graveolens showed large reductions in DIA from ML to FSL. On the other hand, the pioneer species G. ulmifolia showed significant DIA increase when exposed to FSL. The pioneers Croton spp. trended to reduce DIA in $19 \%$, while $R$. elaeocarpum (early or late secondary) showed no significant increase in DIA under FSL condition (table 1). Daily-integrated transpiration was not significantly affected by irradiance regimes in all species. However, the pioneers species trended to exhibit higher transpiration values than early and late secondary ones (table 1), for instance, the transpiration of C. myrianthum (pioneer) was 87.6 and $83.0 \%$ higher than $C$. legalis (late secondary) under ML and FSL conditions respectively.

The irradiance regimes did not affect gs of C. legalis, G. ulmifolia and R. elaeocarpum ( $\mathrm{p}>0.05$ ). $C$. urucurana and $C$. floribundus showed higher gs values $(\mathrm{p}<0.05)$ at noon under ML condition, while A. graveolens and C. myrianthum exhibited statistical differences between irradiance regimes only in the daily gs mean (figure $2 \mathrm{H}-\mathrm{N}$ ).

Effects of high irradiance on daily photochemical efficiency - High irradiance levels at FSL condition caused reduction in potential quantum efficiency of PSII in all species, suggesting photoinhibition as indicated by $\mathrm{F}_{\mathrm{v}} / \mathrm{F}_{\mathrm{m}}$ values smaller than 0.725 (Critchley 1998) (figure 3A-G). Only $C$. legalis did not show recovery of initial $\mathrm{F}_{\mathrm{v}} / \mathrm{F}_{\mathrm{m}}$ values in both irradiance regimes, suffering chronic photoinhibition. The highest $\mathrm{F}_{\mathrm{v}} / \mathrm{F}_{\mathrm{m}}$ values of $C$. legalis were around 0.7 at ML condition (maximal PPFD of $\left.600 \mu \mathrm{mol} . \mathrm{m}^{-2} \cdot \mathrm{s}^{-1}\right)$. In this condition, only $C$. legalis showed $F_{v} / F_{m}$ lower than 0.7 , indicating that PPFD values of $600 \mu \mathrm{mol} \cdot \mathrm{m}^{-2} \cdot \mathrm{s}^{-1} \mathrm{did}$ not decrease the potential photochemical activity for the majority of studied species. As expected, the $F_{v} / F_{m}$ reductions were higher at hours of high PPFD, mainly between 10:30 and 14:30 h, when PPFD values were superior to $1,200 \mu \mathrm{mol} \cdot \mathrm{m}^{-2} \cdot \mathrm{s}^{-1}$. While $C$. urucurana and 


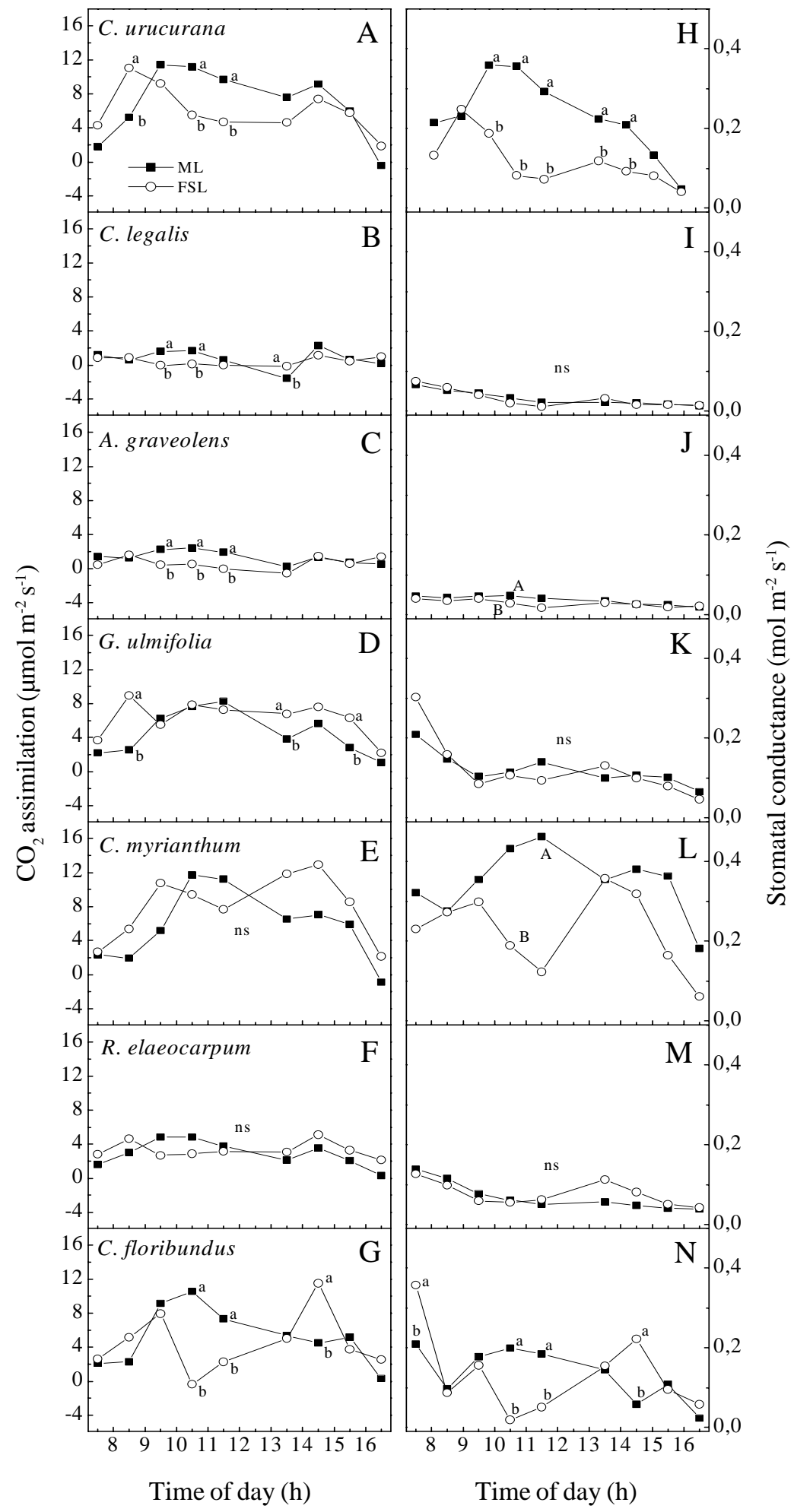

Figure 2. Daily course of $\mathrm{CO}_{2}$ assimilation (A-G) and stomatal conductance (H-N) in seven tropical tree species of different successional status at medium (ML, closed squares) and high (FSL, open circles) irradiance conditions. Each point represents the mean value $(n=3)$. Small letters mean statistical difference $(p<0.05$ by Tukey's test) between irradiance regimes when the interaction irradiance $\mathrm{x}$ time is significant, whereas capital letters mean difference between irradiance regimes (regardless time of day) when the interaction is non-significant. ns represents non-significant differences between irradiance conditions. Pioneer species: C. urucurana (A, H), G. ulmifolia (D, K), C. myrianthum (E, L), and C. floribundus (G, N). Early or late secondary species: A. graveolens $(\mathrm{C}, \mathrm{J})$ and $R$. elaeocarpum $(\mathrm{F}, \mathrm{M})$. Late secondary species: C. legalis $(\mathrm{B}, \mathrm{I})$. 
Table 1. Daily-integrated $\mathrm{CO}_{2}$ assimilation and transpiration referent to the period of measurements (nine hours) of tropical species from different successional groups (according to Gandolfi et al.1995 and Martins \& Rodrigues 2002) under medium (ML) and high (FSL) irradiance conditions. Each value represents the mean value of three replicates. Values in the same line followed by different letters show significant difference between irradiance conditions ( $\mathrm{p}<0.05$, by Tukey's test).

\begin{tabular}{|c|c|c|c|c|c|}
\hline \multirow[t]{2}{*}{ Successional groups } & \multirow[t]{2}{*}{ Species } & \multicolumn{2}{|c|}{$\mathrm{CO}_{2}$ assimilation $\left(\mathrm{mol} . \mathrm{m}^{-2}\right)$} & \multicolumn{2}{|c|}{ Transpiration $\left(\mathrm{mol} . \mathrm{m}^{-2}\right)$} \\
\hline & & ML & FSL & ML & FSL \\
\hline Pioneer & C. urucurana & $0.251 \mathrm{a}$ & $0.202 \mathrm{~b}$ & $134.910 \mathrm{a}$ & $168.282 \mathrm{a}$ \\
\hline Pioneer & C. floribundus & $0.187 \mathrm{a}$ & $0.150 \mathrm{~b}$ & $128.586 \mathrm{a}$ & $108.168 \mathrm{a}$ \\
\hline Pioneer & G. ulmifolia & $0.161 \mathrm{~b}$ & $0.217 \mathrm{a}$ & $128.808 \mathrm{a}$ & $97.338 \mathrm{a}$ \\
\hline Pioneer & C. myrianthum & $0.213 \mathrm{a}$ & $0.283 \mathrm{a}$ & $216.510 \mathrm{a}$ & $203.862 \mathrm{a}$ \\
\hline Early or late secondary & R. elaeocarpum & $0.101 \mathrm{a}$ & $0.109 a$ & $56.526 \mathrm{a}$ & $101.622 \mathrm{a}$ \\
\hline Early or late secondary & A. graveolens & $0.043 \mathrm{a}$ & $0.016 \mathrm{~b}$ & $39.456 \mathrm{a}$ & $35.286 \mathrm{a}$ \\
\hline Late secondary & C. legalis & $0.021 \mathrm{a}$ & $0.011 \mathrm{~b}$ & $26.736 \mathrm{a}$ & $34.692 \mathrm{a}$ \\
\hline
\end{tabular}

$R$. elaeocarpum showed a fast photoinhibition recovery with $\mathrm{F}_{\mathrm{v}} / \mathrm{F}_{\mathrm{m}}$ values measured at $16: 30 \mathrm{~h}$ closer to the initial values $(7: 30 \mathrm{~h})$, A. graveolens, G. ulmifolia, $C$. myrianthum and $C$. floribundus presented a slow photoinhibition recovery. The excessive irradiance effects on photosynthetic apparatus (photoinhibition) were likely exacerbated by high $\mathrm{T}^{\circ} \mathrm{C}$ observed during measurements, reaching values around $39^{\circ} \mathrm{C}$.

The higher values of effective quantum efficiency of PSII $\left(\Delta \mathrm{F} / \mathrm{F}_{\mathrm{m}}{ }^{\prime}\right)$ of all species were recorded at ML condition (figure $3 \mathrm{H}-\mathrm{N}$ ). As PPFD increased, $\Delta \mathrm{F} / \mathrm{F}_{\mathrm{m}}$, values decreased in both irradiance regimes $(\mathrm{p}<0.05)$. C. legalis and R. elaeocarpum showed similar $\Delta \mathrm{F} / \mathrm{F}_{\mathrm{m}}$, reduction independent from irradiance regime whereas the other species had smaller $\Delta \mathrm{F} / \mathrm{F}_{\mathrm{m}}$ ' reduction under $\mathrm{ML}$ condition (figure $3 \mathrm{H}-\mathrm{N}$ ). The apparent electron transport rate (ETR) was also influenced by irradiance regimes (figure 4A-G). Higher ETR values were found under higher PPFD, except for $C$. legalis that did not show significant differences between the irradiance regimes. C. urucurana, A. graveolens, C. myrianthum, and C. floribundus had similar ETR dynamic at FSL condition, with higher rates from 8:30 to 9:30 $\mathrm{h}$ and $15: 30 \mathrm{~h}$, showing evident ETR decrease at hours of higher PPFD, $\mathrm{T}^{\circ} \mathrm{C}$, and $\mathrm{VPD}_{\text {leaf-air }}$ This ETR decline was less pronounced and was not verified for G. ulmifolia and R. elaeocarpum. The highest ETR values were observed in FSL, at 9:30 h for C. urucurana, C. myrianthum, and C. floribundus. At ML conditions, the highest ETR was recorded between 10:30 and 14:30 h for the majority of species, accompanying the increase in PPFD. So, the favorable environment promoted by ML condition did not induce ETR decreases at hours of higher atmospheric demand and PPFD, contrary to what was observed under FSL condition.

The photochemical quenching (qP) (data not shown) reflected the same $\Delta \mathrm{F} / \mathrm{F}_{\mathrm{m}}$ ' dynamics, indicating that a larger amount of absorbed energy (larger $\Delta \mathrm{F} / \mathrm{F}_{\mathrm{m}}$ ' values) was driven to photochemical reactions of photosynthesis (larger qP values) (Bolhàr-Nordenkampf $\&$ Öquist 1993). The non-photochemical quenching (NPQ), represented by energy dissipation processes related to the interconversion of xanthophylls and heat formation (Bilger \& Björkman 1990, Demmig-Adams \& Adams 1992), was affected by irradiance regimes (figure 4H-N). Except for C. legalis, all other species presented the same behavior, where the NPQ values were larger at FSL condition, accompanying the increase in PPFD. Maximum NPQ values were recorded at 10:30 $\mathrm{h}$ at FSL, while the highest NPQ values at ML condition were found at early morning. NPQ trended to decrease during the day at ML, when minimum NPQ values were observed at 16:30 h. As for qP, C. legalis did not show significant differences in NPQ when the irradiance regimes were compared.

Successional groups ordination by multivariate analysis - Principal component analysis (PCA), performed taking into account the whole physiological parameters measured in each environmental condition, showed a sharp pattern of ordination among the species similar to the classification of successional groups (figure 5). According to PCA analysis, the most important physiological parameters to the species ordination under ML conditions were, in decreasing order: $\Delta \mathrm{F} / \mathrm{F}_{\mathrm{m}}{ }{ }, \mathrm{ETR}, \mathrm{NPQ}, \mathrm{F}_{\mathrm{v}} / \mathrm{F}_{\mathrm{m}}, \mathrm{qP}, \mathrm{A}, \mathrm{E}, \mathrm{gs}$, and Ci. In the ordination graph, the pioneer species were grouped on left side, whereas the late secondary species 


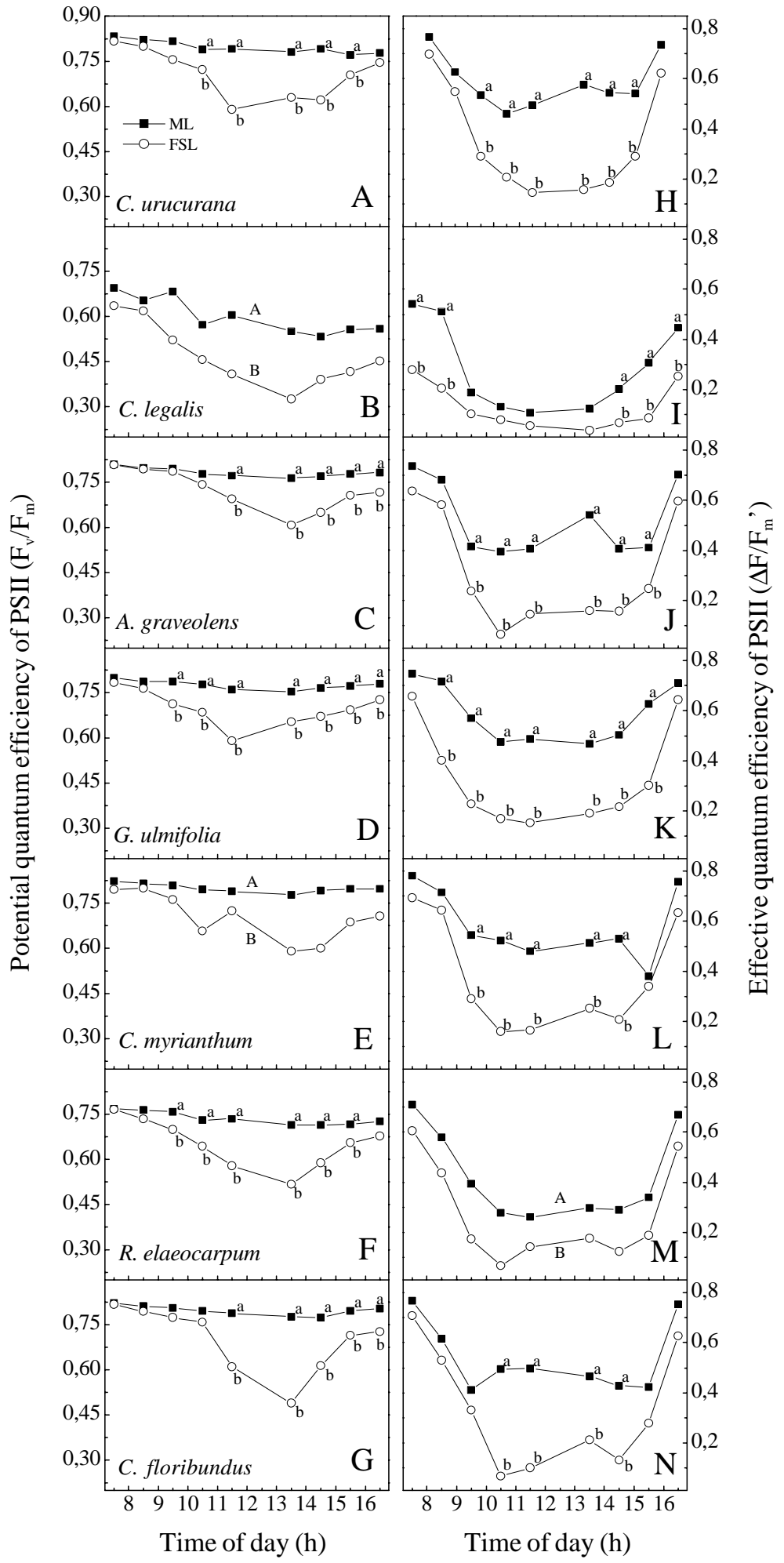

Figure 3. Daily course of potential (A-G) and effective (H-N) quantum efficiency of photosystem II (PSII) in seven tropical tree species of different successional status at medium (ML, closed squares) and high (FSL, open circles) irradiance conditions. Each point represents the mean value $(n=3)$. Small letters mean statistical difference $(p<0.05$ by Tukey's test) between irradiance regimes when the interaction irradiance $x$ time is significant, whereas capital letters mean difference between irradiance regimes (regardless time of day) when the interaction is non-significant. Pioneer species: C. urucurana (A, H), G. ulmifolia (D, $\mathrm{K}), C$. myrianthum $(\mathrm{E}, \mathrm{L})$, and $C$. floribundus $(\mathrm{G}, \mathrm{N})$. Early or late secondary species: A. graveolens $(\mathrm{C}, \mathrm{J})$ and $R$. elaeocarpum (F, M). Late secondary species: C. legalis (B, I). 


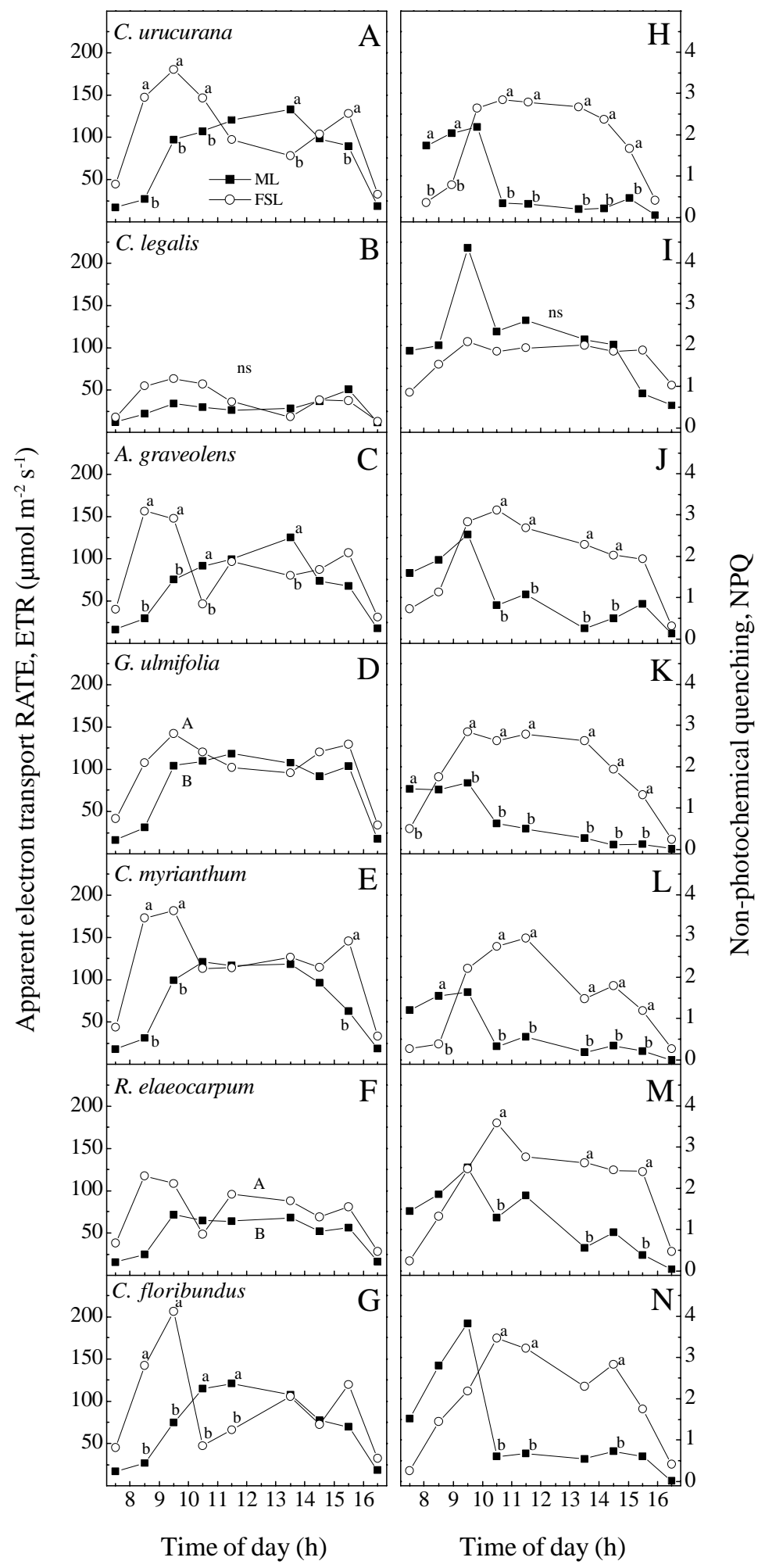

Figure 4. Daily course of apparent electron transport rate (A-G) and non-photochemical quenching (H-N) in seven tropical tree species of different successional status at medium (ML, closed squares) and high (FSL, open circles) irradiance conditions. Each point represents the mean value $(n=3)$. Small letters mean statistical difference $(p<0.05$ by Tukey's test) between irradiance regimes when the interaction irradiance $x$ time is significant, whereas capital letters mean difference between irradiance regimes (regardless time of day) when the interaction is non-significant. ns represents non-significant differences between irradiance conditions. Pioneer species: C. urucurana $(\mathrm{A}, \mathrm{H})$, G. ulmifolia $(\mathrm{D}, \mathrm{K})$, C. myrianthum $(\mathrm{E}, \mathrm{L})$, and C. floribundus $(\mathrm{G}$, $\mathrm{N})$. Early or late secondary species: A. graveolens $(\mathrm{C}, \mathrm{J})$ and $R$. elaeocarpum $(\mathrm{F}, \mathrm{M})$. Late secondary species: C. legalis $(\mathrm{B}, \mathrm{I})$. 
C. legalis was placed on the right side (figure 5A). A. graveolens and $R$. elaeocarpum were placed closer to the center of the graph. The ordination graph considering the measurements scored under FSL condition (figure 5B) indicated a similar species distribution in relation to ML, except that $A$. graveolens was closer to the late secondary species $C$. legalis. The physiological parameters more important to determine species ordination were different from those under ML. $\mathrm{CO}_{2}$ assimilation and transpiration rates played an important role to the species ordination, being followed by ETR, $\Delta F / F_{m}$ ', gs, $q P, F_{v} / F_{m}, C i$, and NPQ.

\section{Discussion}

Stomatal apparatus and photochemical activity have important roles on the photosynthetic process (Zeiger et al. 1987, Long et al. 1994, Critchley 1998). Photosynthesis is affected by stomatal closure, decreasing $\mathrm{CO}_{2}$ influx to mesophyll (Farquhar \& Sharkey 1982, Nobel 1999). Similar trends of gs and A suggested stomatal limitation in C. floribundus, $C$. urucurana, and C. myrianthum under FSL, and in G. ulmifolia and C. myrianthum under ML condition (figure 2). The lowest E values under FSL were caused
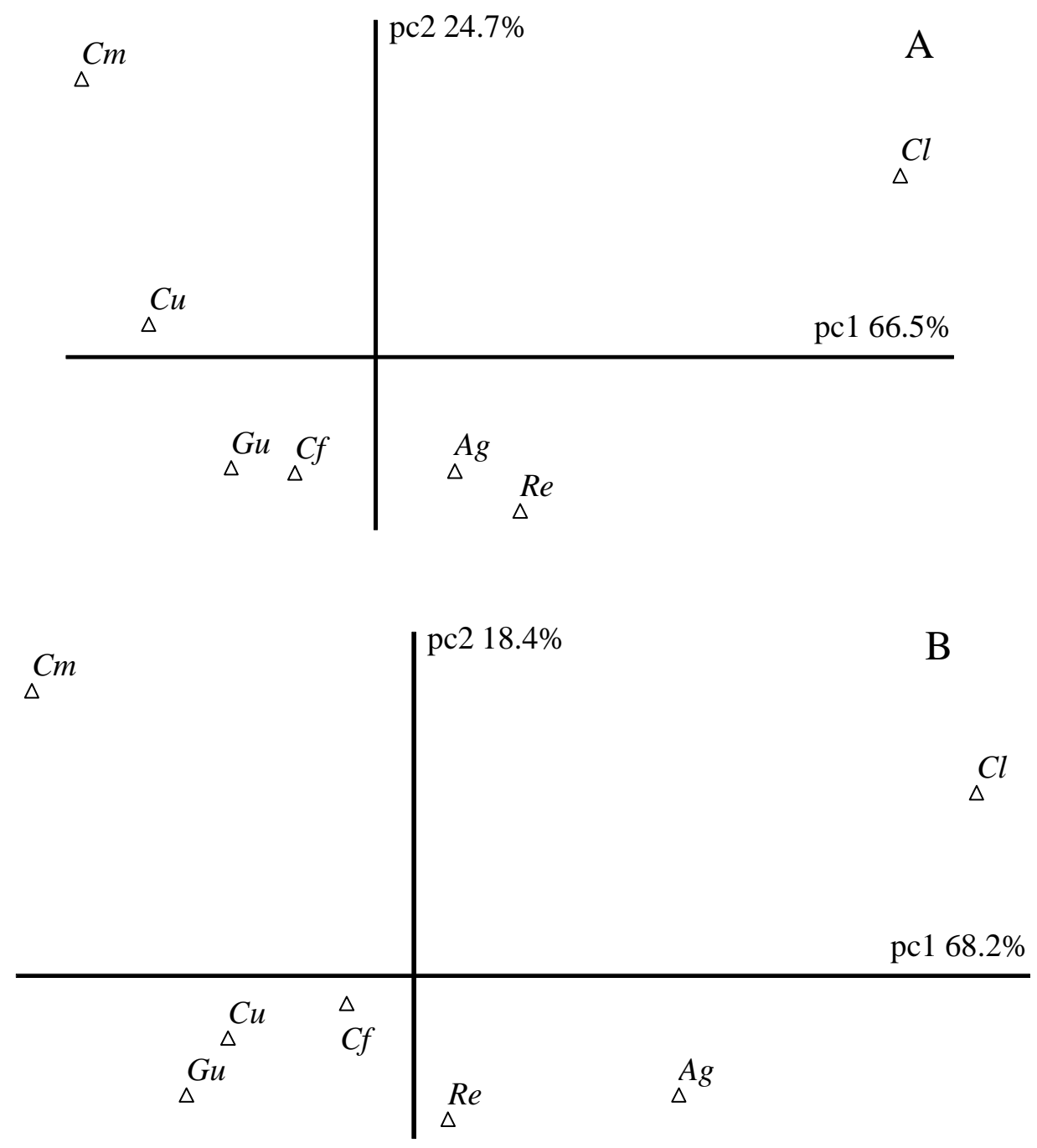

Figure 5. Ordination graph of principal component analysis (PCA) of studied species under medium (A) and high (B) irradiance conditions. $\mathrm{Cu}, C$. urucurana (pioneer); $\mathrm{Cl}, C$. legalis (late secondary); $\mathrm{Ag}$, A. graveolens (early or late secondary); $\mathrm{Gu}, G$. ulmifolia (pioneer); Cm, C. myrianthum (pioneer); Re, R. elaeocarpum (early or late secondary); Cf, C. floribundus (pioneer). The percentages of variability explanation are depicted in each axis. 
by gs decrease due to higher $\mathrm{VPD}_{\text {leaf-air }}$ values. This observation indicates that the stomatal response to increasing $\mathrm{VPD}_{\text {leaf-air }}$ was a mechanism to maintain the plant water status at the expenses of low photosynthetic rates (Jones 1998, Nobel 1999). It is important to emphasize that C. floribundus, C. urucurana, C. myrianthum, and G. ulmifolia are early successional species and any mechanism to prevent water loss may be important to their capacity of occupying gaps exposed to high irradiance, temperature, and $\mathrm{VPD}_{\text {leaf-air }}$. C. myrianthum showed stomatal constraint of photosynthesis in both ML and FSL conditions probably because this species is typical from humid areas (Lorenzi 1992), where there is low atmospheric demand (low $\mathrm{VPD}_{\text {leaf-air }}$ ).

Photochemical activity was affected by high irradiance condition with further effects on photosynthesis rate. Photochemical activity may influence the photosynthesis due to decreasing efficiency of light use (Long et al. 1994, Critchley 1998). Changes in $\mathrm{F}_{\mathrm{v}} / \mathrm{F}_{\mathrm{m}}$ may play a photoprotection role, or indicate damage at PSII reaction center. The former is named dynamic photoinhibition, and according to Osmond (1994) is a decline in light capture efficiency that does not involve a decrease in photosynthetic capacity, being rapidly reversible. Decreases in the light absorption efficiency could prevent the generation of reactive oxygen species and consequent photooxidation (Demmig-Adams \& Adams 1992, Foyer et al. 1994, Thiele et al. 1996). The chronic photoinhibition is slowly reversible and it is associated to reduced maximal $\mathrm{CO}_{2}$ assimilation rate (Osmond 1994). Dynamic photoinhibition observed in $C$. urucurana, $A$. graveolens, and $R$. elaeocarpum, even though working as a photoprotective mechanism, affected the photosynthesis under FSL condition for a moment. C. legalis was the only species that showed chronic photoinhibition, being its photosynthesis also affected by decreasing photochemical capacity, markedly under FSL condition. Considering the role of photochemical reactions as a source of ATP and NADPH for photosynthetic activity, we could consider ETR as a fundamental parameter to evaluate the photosynthetic process. This was supported by the similar diurnal courses of A and ETR in all species with exception of C. legalis and A. graveolens (figures $2 \mathrm{~A}-\mathrm{G}, 4 \mathrm{~A}-\mathrm{G}$ ). The limitation of photosynthesis by ETR was observed in $C$. floribundus and C. urucurana, markedly under FSL condition. Based on photochemical results, we suggest that the type of photoinhibition could be a remarkable feature in order to identify successional groups, since the late secondary species was the only one that showed chronic photoinhibition. This hypothesis was supported by Chazdon et al. (1996) that reported that photoinhibition was lower in early successional species than in late ones under gap condition.

According to Krause et al. (2001), the higher degree of photoinhibition observed in late successional species indicates which this species experienced higher light stress. As observed by Kitajima (1994) and Ellis et al. (2000), the higher photosynthetic rates of early successional species could be an important quencher of excessive light energy. In addition, high transpiration may contribute to decrease photoinhibition in early successional plants by cooling leaves and maintaining high photosynthetic rates (Krause et al. 2001). Photoinhibition recovery in some species also reflects a dynamic regulatory mechanism of thermal energy dissipation (indicated by NPQ values) that allows plants to cope with periods of high irradiance (Krause \& Winter 1996).

In the current paradigm of ecophysiology of tropical species there are two main hypotheses about the differences on flexibility of responses to environmental changes between early and late successional species. The hyphotesis of the multiple-resource model (Bazzaz \& Pickett 1980) takes into account the high variability of resources (nutrients, light, and water) in early successional environments. It hypothesizes that permanent understorey species may exhibit a 'struggler' metabolism that is adapted to low levels of resource flux, whereas species that depend on gaps have higher and more flexible metabolic rates capable to respond to resource pulses. The second hyphotesis, the singleresource model, is essentially based on light resources. It proposes that late successional species that eventually reach the forest canopy are especially sensitive to variations in irradiance (Pearcy 1987). Our results, considering overall photosynthetic performance (figures 2A-G, 3, 4), support the hypothesis of more flexible responses of early successional species proposed by Bazzaz \& Pickett (1980). The late successional species showed a lower and more constant photosynthetic behavior than early ones in both irradiance regimes.

The results based on daily-integrated $\mathrm{CO}_{2}$ assimilation indicated that all species showed some level of phenotypic plasticity to FSL condition. While $C$. myrianthum and $R$. elaeocarpum exhibited higher homeostatic capacity, the other species trended to decrease DIA under FSL condition, with exception of G. ulmifolia (table 1). So, we can conclude G. ulmifolia was the only species to respond positively and 
significantly to increasing irradiance. As the photochemical responses of G. ulmifolia were similar to the other early successional species, we can suppose that its higher daily $\mathrm{CO}_{2}$ assimilation under FSL was due to the carboxylation efficiency of Calvin cycle.

The photochemical parameter $\Delta \mathrm{F} / \mathrm{F}_{\mathrm{m}}{ }^{\prime}$ indicated that all species responded to the FSL condition, markedly between 9:30 and 15:30 h. Considering other photochemical parameters, such as ETR and NPQ, C. legalis was the only species that did not show significant differences between ML and FSL conditions. Therefore, since this species showed signals of chronic photoinhibition and had an accentuated DIA reduction, we can argue that $C$. legalis is a shade-tolerant species. Although the other species have shown dynamic photoinhibition, they exhibited an efficient homeostatic mechanism, as suggested by $F_{v} / F_{m}$ recovery at late evening (figure $3 \mathrm{~A}-\mathrm{G}$ ).

The above considerations refer to another fundamental concept in ecology: competition. The maintenance of high capacity of light interception with canopy developing is of primary importance to hold competitive advantage. Stem elongation is an important feature ensuring that young leaves may be exposed to direct sun-light, improving the interception of light energy at first stages of forest succession (Ballare 1996). The early successional species evaluated in this study exhibited higher initial growth rates (IGR) than the late ones. C. urucurana and G. ulmifolia showed IGR values of 10.10 and $8.83 \mathrm{~cm} . \mathrm{month}^{-1}$, respectively, whereas IGR of $C$. legalis was $3.78 \mathrm{~cm}$. month ${ }^{-1}$. These data suggest that early successional species could have a competitive advantage in the early stages of forest succession, regarding the light harvesting.

Another important issue that must be taken into account to study the occupation processes of areas exposed to high irradiance is the thermal dissipation capacity of the excessive light energy (Demmig-Adams \& Adams 1992, Scholes et al. 1997). As suggested by Scholes et al. (1997) and verified in this study, NPQ changes had an essential role as a thermal dissipative process when plants were submitted to high irradiance condition. In the PSII, the excitation energy can be nonradiatively transformed into heat, which is indicated by NPQ parameter. This energy transduction was higher in FSL, suggesting that NPQ was an important mechanism to maintain the function of PSII (DemmigAdams \& Adams 1992). The NPQ increase may reflect an increase in zeaxanthin formation since it is well established that both the time course and magnitude of NPQ in leaves are strongly correlated with zeaxanthin formation under a wide range of conditions (Björkman $\&$ Demmig-Adams 1994). Our results showed that the typical late secondary species $C$. legalis was the only species that did not show NPQ increase under FSL condition (figure 4I), indicating inability to dissipate the excessive light energy, compromising its $\mathrm{CO}_{2}$ assimilation capacity (table 1).

The multivariate analysis revealed physiological differences between early and late successional species also characterizing a mid-successional group (early secondary) represented by $A$. graveolens and $R$. elaeocarpum. These results suggest that early successional species can be subdivided in pioneer and early secondary species. This classification is in accordance with Gandolfi et al. (1995), Kammesheidt (2000), Köhler et al. (2000), Aidar et al. (2003), and Withmore (1996) that suggest a continuum of ecophysiological response among gap-phase gradient species. In addition, this analysis suggests a changing in the importance of photosynthetic parameters under different irradiance levels. Photochemical parameters, mainly $\Delta \mathrm{F} / \mathrm{F}_{\mathrm{m}}$ ' and ETR, were more suitable to separate the successional groups under ML condition. Ribeiro et al. (2004) also reported that the $\Delta \mathrm{F} / \mathrm{F}_{\mathrm{m}}$ ' was the most suitable parameter to distinguish pioneer, early and late secondary species growing in a gap of a semi-deciduous forest where irradiance was similar to ML condition in this study. On the other hand, A and E play a major role to separate the successional groups under FSL condition. Our results indicate that ecophysiological studies are relevant in planning and elaborating adequate strategies for reforestation and recovery of degraded areas. However, complementary studies considering the aspects of water availability are quite important to the understanding of tropical species physiology (Souza et al. 2004).

Acknowledgements - Dr. Ricardo R. Rodrigues, Dr. Sergius Gandolfi and Dr. Antonio N. Gonçalves (Esalq/Usp, Brazil) are thanked for their critical comments about this work. We are also grateful to André G. Nave for the plant material. G.M. Souza and R.V. Ribeiro are grateful to Fundação de Amparo à Pesquisa do Estado de São Paulo (Fapesp, Brazil) and E.C. Machado is grateful to Conselho Nacional de Desenvolvimento Científico e Tecnológico (CNPq, Brazil).

\section{References}

AIDAR, M.P.M., SCHMIDT, S., MOSS, G., STEWART, G.R. \& JOLY, C.A. 2003. Nitrogen use strategies of neotropical rainforest trees in threatened Atlantic Forest. Plant Cell and Environment 26:389-399. 
BALLARÉ, C.L. 1996. Light gaps: sensing the light opportunities in highly dynamic canopy environments. In Explotation of environmental heterogeneity by plants (M.M. Caldwell \& R.W. Pearcy, eds.). Academic Press, San Diego, p.73-109.

BAZZAZ, F.A. 1996. Plants in changing environments. Cambridge University Press, Cambridge.

BAZZAZ, F.A. \& PICKETT, S.T.A. 1980. Physiological ecology of tropical succession: a comparative review. Annual Review of Ecology and Systematics 11:287-310.

BILGER, W. \& BJÖRKMAN, O. 1990. Role of xanthophyll cycle in photoprotection elucidated by measurements of light induced absorbance changes, fluorescence and photosynthesis in leaves of Hedera canariensis. Photosynthesis Research 25:173-185.

BJÖRKMAN, O. \& DEMMIG-ADAMS, B. 1994. Regulation of photosynthetic light energy capture, conversion and dissipation in leaves of higher plants. In Ecophysiology of photosynthesis (E.-D. Schulze \& M.M. Caldwell, eds.). Springer, New York, p.17-47.

BOLHÀR-NORDENKAMPF, H.R. \& ÖQUIST, G.O. 1993. Chlorophyll fluorescence as a tool in photosynthesis research. In Photosynthesis and production in a changing environment: a field and laboratory manual (D.O. Hall, J.M.O. Scurlock, H.R. Bolhàr-Nordenkampf, R.C. Leegood \& S.P. Long, eds.). Chapman \& Hall, London, p.193-206.

CANNON, W. B. 1932. The wisdom of the body. Norton, New York.

CHAZDON, R.L., PEARCY, R.W., LEE, D.W. \& FETCHER, N. 1996. Photosynthetic responses of tropical forest plants to contrasting light environments. In Tropical forest plant ecophysiology (S.S. Mulkey, R.L. Chazdon \& A.P. Smith, eds.). Chapman \& Hall, New York, p.5-55.

CRITCHLEY, C. 1998. Photoinhibition. In Photosynthesis, a comprehensive treatise (A.S. Raghavendra, ed.). Cambridge University Press, Cambridge, p.264-272.

DEMMIG-ADAMS, B. \& ADAMS, W.W. 1992. Photoprotection and other responses of plants to highlight stress. Annual Review of Plant Physiology and Plant Molecular Biology 43:599-626.

DEMMIG, B. \& BJÖRKMAN, O. 1987. Comparison of the effects of excessive light on chlorophyll fluorescence $(77 \mathrm{~K})$ and photon yield of $\mathrm{O}_{2}$ evolution in leaves of higher plants. Planta 171:171-184.

ELLIS, A.R., HUBBELL, S.P. \& POTVIN, C. 2000. In situ field measurements of photosynthetic rates of tropical tree species: a test of the functional group hypothesis. Canadian Journal of Botany 78:1336-1347.

FARQUHAR, G.D. \& SHARKEY, T.D. 1982. Stomatal conductance and photosynthesis. Annual Review of Plant Physiology 33:317-345.

FOYER, C.H., DESCOURVIÈRES, P. \& KUNERT, K.J. 1994. Protection against oxygen radicals: an important defense mechanism studied in transgenic plants. Plant Cell and Environment 17:507-523.
GANDOLFI, S., LEITÃO FILHO, H.F. \& BEZERRA, C.L.F. 1995. Levantamento florístico e caráter sucessional das espécies arbustivo-arbóreas de uma Floresta Mesófila Semidecídua no município de Guarulhos. Brazilian Journal of Biology 55:753-767.

GENTY, B., BRIANTAIS, J.M. \& BAKER, N.R. 1989. The relationship between the quantum yield of photosynthetic electron transport and quenching of chlorophyll fluorescence. Biochimica et Biophysica Acta 990:87-92.

JONES, H.G. 1998. Stomatal control of photosynthesis and transpiration. Journal of Experimental Botany 49:387-398.

KAMMESHEIDT, L. 2000. Some autoecological characteristics of early to late successional tree species in Venezuela. Acta Oecologia 21:37-48.

KAUFFMAN, S.A. 1993. The origins of order. Oxford University Press, New York.

KITAJIMA, K. 1994. Relative importance of photosynthetic traits and allocation patterns as correlates of seedling ML tolerance of 13 tropical trees. Oecologia 98:419-428.

KÖHLER, P., DITZER, T. \& HUTH, A. 2000. Concepts for the aggregation of tropical tree species into functional types and the application to Sabah's lowland rain forests. Journal of Tropical Ecology 16:591-602.

KRALL, J.P. \& EDWARDS, G.E. 1992. Relationship between photosystem II activity and $\mathrm{CO}_{2}$ fixation in leaves. Physiologia Plantarum 86:180-187.

KRAUSE, G.H. \& WINTER, K. 1996. Photoinhibition of photosynthesis in plants growing in natural tropical forest gaps: a chlorophyll fluorescence study. Botanica Acta 109:456-462.

KRAUSE, G.H., KOROLEVA, O.Y., DALLING, J.W. \& WINTER, K. 2001. Acclimation of tropical tree seedlings to excessive light in simulated tree-fall gaps. Plant, Cell and Environment 24:1345-1352.

LAISK, A., RASUlOV, B.H. \& LORETO, F. 1998. Thermoinhibition of photosynthesis as analyzed by gas exchange and chlorophyll fluorescence. Russian Journal of Plant Physiology 45:412-421.

LONG, S.P., HUMPHRIES, S. \& FALKOWSKI, P.G. 1994. Photoinhibition of photosynthesis in nature. Annual Review of Plant Physiology and Plant Molecular Biology 45:633-662.

LORENZI, H. 1992. Árvores brasileiras: manual de identificação e cultivo de plantas arbóreas nativas do Brasil. Plantarum, Nova Odessa.

LUKEN, J.O. 1990. Directing ecological succession. Chapman \& Hall, London.

MANLY, B.F.J. 1994. Multivariate statistical methods. Chapman \& Hall, London.

MARTINS, S.V. \& RODRIGUES, R.R. 2002. Gap-phase regeneration in a semideciduous mesophytic forest, south-eastern Brazil. Plant Ecology 163:51-62.

MCGARIGAL, K., CUSHMAN, S. \& STAFFORD, S. 2000. Multivariate statistics for wildlife and ecology research. Springer-Verlag, New York. 
MØLLER, A.P. \& SWADDLE, J.P. 1997. Asymmetry, developmental stability, and evolution. Oxford University Press, Oxford.

MULKEY, S.S., WRIGHT, S.J. \& SMITH, A.P. 1993. Comparative physiology and demography of three Neotropical shrubs: alternative shade-adaptive character syndromes. Oecologia 96:526-536.

NOBEL, P.S. 1999. Physicochemical \& environmental plant physiology. Academic Press, San Diego.

OSMOND, C.B. 1994. What is photoinhibition? Some insights from comparisons of shade and sun plants. In Photoinhibition of photosynthesis, from molecular mechanisms to the field (N.R. Baker \& J.R. Bowyer, eds.). Bios Scientific, Oxford, p.1-24.

PEARCY, R.W. 1987. Photosynthetic gas exchange responses of Australian tropical forest trees in canopy, gap and understorey micro-environments. Functional Ecology 1:169-178.

PICKETT, S.T.A., COLLINS, S.L. \& ARNESTO, J.J. 1987. A hierarchical consideration of causes and mechanisms of succession. Vegetatio 69:109-114.

RIBEIRO, R.V., SOUZA, G.M., MANZATTO, A.G., MACHADO, E.C. \& OLIVEIRA, R.F. 2004. Chlorophyll fluorescence of tropical tree species in a semi-deciduous forest gap. Revista Árvore 28:21-27.

SCHLICHTING, C.D. \& SMITH, H. 2002. Phenotypic plasticity: linking molecular mechanisms with evolutionary outcomes. Evolutionary Ecology 16:189-211.
SCHOLES, J.D., PRESS, M.C. \& ZIPPERLEN, S.W. 1997. Differences in light energy utilisation and dissipation between dipterocarp rain forest tree seedlings. Oecologia 109:41-48.

SOUZA, G.M., RIBEIRO, R.V., SANTOS, M.G., RIBEIRO, H.L. \& OLIVEIRA, R.F. 2004. Functional groups of forest succession as dissipative structures: an applied study. Brazilian Journal of Biology 64:709-720.

STRAUSS-DEBENEDETTI, S. \& BAZZAZ, F.A. 1996. Photosynthetic characteristics of tropical trees along successional gradients. In Tropical forest plant ecophysiology (S.S. Mulkey, R.L. Chazdon \& A.P. Smith, eds.). Chapman \& Hall, New York, p.162-186.

THIELE, A., SCHIRWITZ, K., WINTER, K. \& KRAUSE, G.H. 1996. Increased xanthophyll cycle activity and reduced D-1 protein inactivation related to photoinhibition in two plant systems acclimated to excess light. Plant Science 115:237-250.

VAN KOOTEN, O. \& SNEL, J.F.H. 1990. The use of chlorophyll fluorescence nomenclature in plant stress physiology. Photosynthesis Research 25:147-150.

WITHMORE, T.C. 1996. A review of some aspects of tropical rain forest seedling ecology with suggestions for further enquiry. In Ecology of tropical forest tree seedlings (M.D. Swaine, ed.). Man and Biosphere series vol. 17. UNESCO/Pathernon, Paris, p.3-39.

ZEIGER, E., FARQUHAR, G.D. \& COWAN, I.R. (eds.) 1987. Stomatal function. Stanford University Press, Stanford. 